\title{
New avenues in the medical treatment of Cushing's disease: corticotroph tumor targeted therapy
}

\author{
Maria Fleseriu - Stephan Petersenn
}

Received: 25 February 2013/Accepted: 6 May 2013/Published online: 15 May 2013

(c) The Author(s) 2013. This article is published with open access at Springerlink.com

\begin{abstract}
Cushing's disease (CD) is a condition of chronic hypercortisolism caused by an adrenocorticotropic hormone-secreting pituitary adenoma. First-line transsphenoidal surgery is not always curative and disease sometimes recurs. Radiotherapy often requires months or years to be effective, and is also not curative in many cases. Consequently, effective medical therapies for patients with $\mathrm{CD}$ are needed. Corticotroph adenomas frequently express both dopamine (D2) and somatostatin receptors (predominantly $\operatorname{sstr}_{5}$ ). Pasireotide, a somatostatin analog with high sstr $_{5}$ binding affinity, has shown urinary free cortisol (UFC) reductions in most patients with $\mathrm{CD}$ in a large phase 3 trial, with UFC normalization and tumor shrinkage in a subset of patients. Adverse events were similar to other somatostatin analogs, with the exception of the degree and severity of hyperglycemia. Two small trials (one prospective and one retrospective) have suggested that cabergoline, a D2 receptor agonist, could be effective in normalizing UFC, but current long-term data results are conflicting. Combination treatment with pasireotide plus cabergoline and the adrenal steroidogenesis inhibitor ketoconazole has been successful, but further investigation in larger trials is necessary. Retinoic acid also showed interesting results in a recent very small prospective study. Glucocorticoid receptor blockade with mifepristone has recently demonstrated improvement in
\end{abstract}

\section{Fleseriu ( $₫)$}

Departments of Medicine and Neurological Surgery, and Northwest Pituitary Center, Oregon Health \& Science University, Mail Code BTE472, 3181 S. W. Sam Jackson Park Road, Portland, OR 97239, USA

e-mail: fleseriu@ohsu.edu

S. Petersenn

ENDOC Center for Endocrine Tumors, Altonaer Str. 59, 20357 Hamburg, Germany signs and symptoms of Cushing's and glycemic control; however, this modality does not address the etiology of the disease and has inherent adverse events related to its mechanism of action. Pituitary-targeted medical therapies will soon play a more prominent role in treating $\mathrm{CD}$, and may potentially become first-line medical therapy when surgery fails or is contraindicated.

Keywords Cushing's disease $\cdot$ Pituitary corticotroph adenoma Somatostatin analog $\cdot$ Cabergoline $\cdot$ Pasireotide Retinoic acid

\section{Introduction}

Cushing's disease (CD) is a condition of hypercortisolism caused by an adrenocorticotropic hormone (ACTH)secreting pituitary adenoma. While rare, it is associated with significant morbidity and mortality [1-3].

Pituitary secretion of ACTH is normally regulated by hypothalamic and paracrine signals, and through negative feedback by glucocorticoids [4]. Systemic ACTH levels also exhibit a circadian rhythm, controlled by the suprachiasmatic nucleus and entrained by light-dark cycles [4]. Superimposed on this circadian rhythm is an ultradian cycle of pulsatile ACTH release, which is closely mimicked by cortisol levels (Fig. 1a) [5-7]. In patients with CD, both basal and peak ACTH levels are elevated (Fig. 1b), and ACTH and cortisol levels are uncoordinated [5-10].

For most patients with $\mathrm{CD}$, primary treatment is transsphenoidal surgery to remove the pituitary adenoma. However, success rates are variable (reported as 65 to $90 \%$ ) and dependent on the surgeon's expertise [11]. Published 5- and 10-year recurrence rates are as high as 25 and $56 \%$, respectively $[12,13]$, and many patients develop 


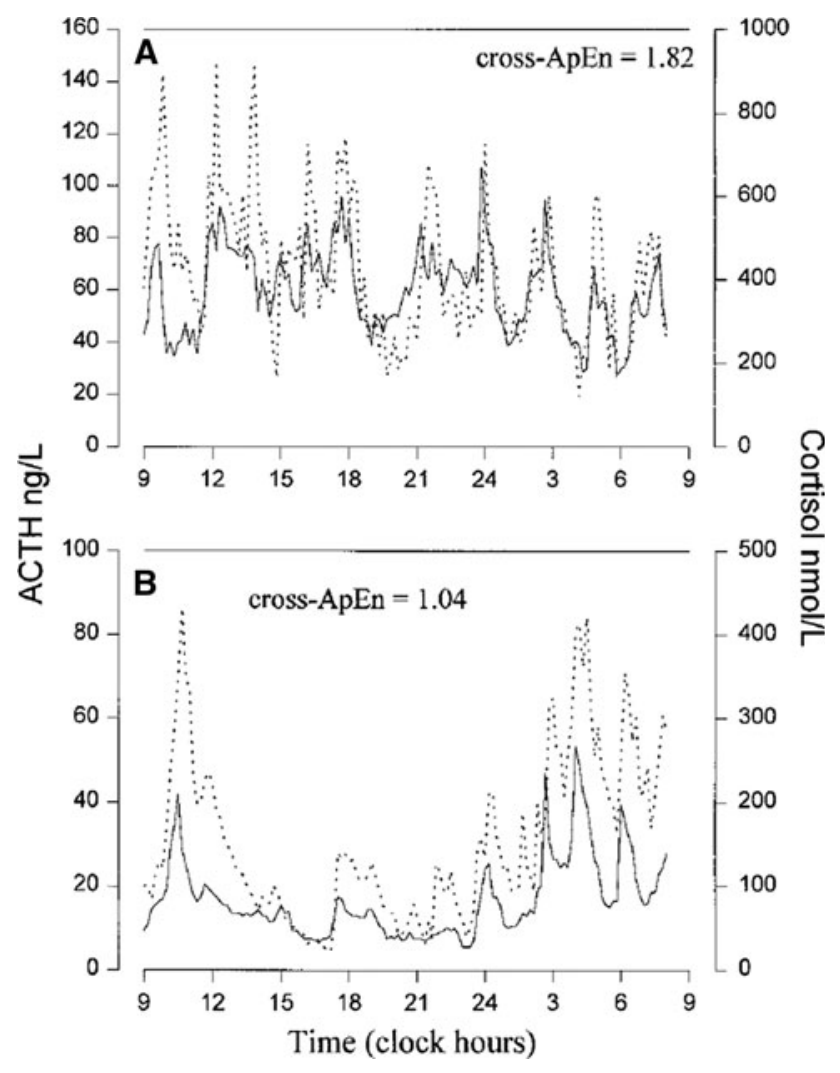

Fig. 1 24-hour plasma levels of ACTH (dotted line) and cortisol (solid line) in a normal female (a) and a female patient with Cushing's disease (b). Note that in $\mathrm{CD}$, both basal and peak cortisol levels are elevated, and cortisol secretion is less synchronized to ACTH levels. From Roelfsema F, Pincus SM, Veldhuis JD (1998) J Clin Endocrinol Metab, volume 83, page 690 [7]. Reproduced with permission

deficiencies of other pituitary hormones post-surgery [11]. Patients who fail to achieve or maintain remission require secondary treatment, including radiotherapy and/or adrenalectomy-both of which are associated with subsequent hormone deficiencies [11]. Thus, additional treatment options for patients with $\mathrm{CD}$ are required.

While there are several potential CD therapeutic targets, there is relatively little clinical experience with most medical treatments. Recently, however, prospective studies have demonstrated promise for pituitary-directed medical interventions targeting the underlying adenoma.

\section{Potential pituitary targets and pituitary-targeted therapies for corticotroph adenomas}

Somatostatin receptors in the pituitary and pituitary adenomas

Somatostatin often serves to inhibit secretory responses, but also exhibits antiproliferative effects in some tissues [14]. Somatostatin receptors are widespread throughout the central nervous system and in several peripheral tissues $[15,16]$. To date, 5 somatostatin receptor subtypes (sstr) have been identified and cloned ( $\operatorname{sstr}_{1}-$ sstr $\left._{5}\right)$ [14]. Immunostaining indicates that normal human anterior pituitary expresses all 5 subtypes, and that most corticotroph adenomas express $\geq 1$ sstr [17-19]. While expression levels are highly variable, $\operatorname{sstr}_{2}$ and $\operatorname{sstr}_{5}$ are most consistently expressed, and $\operatorname{sstr}_{4}$ is generally absent $[17,19]$. A study using quantitative RT-PCR and immunohistochemistry found that human corticotroph adenomas expressed $\operatorname{sstr}_{1,2,4}$ and 5 , and that $\operatorname{sstr}_{5}$ had the highest expression levels in 10/12 adenomas [20].

Differential sstr expression levels between somatotroph and corticotroph adenomas may partly explain why octreotide, which has relative selectivity for $\mathrm{sstr}_{2}$, inhibits growth hormone secretion from somatotroph adenomas but has little effect on ACTH secretion from corticotroph adenomas [19]. Somatostatin has also been shown to inhibit ACTH secretion from pituitary cells taken from adrenalectomized rats [21], and reduced serum ACTH levels in humans who had hypocortisolism [22-24], but did not affect ACTH secretion from pituitary cells taken from normal rats $[25,26]$ or ACTH levels in patients with $\mathrm{CD}$ $[17,19,27-29]$. These findings suggested that high corticosteroid levels were associated with low responsiveness to $\mathrm{sstr}_{2}$-specific analogs in corticotroph adenomas. This conclusion is supported by the observation that the ability of somatostatin or octreotide to inhibit ACTH secretion from cultured corticotroph adenoma cells was abolished by pretreatment with dexamethasone [30].

These findings have produced a working model of the regulation of ACTH secretion by corticotroph adenomas [31, 32], wherein high systemic cortisol downregulates $\operatorname{sstr}_{2}$ expression in the corticotroph adenoma cells, rendering $\operatorname{sstr}_{2}$ agonists ineffective at inhibiting ACTH secretion. In contrast, sstr $_{5}$ expression appears to be relatively unaffected by high cortisol levels. Upon treatment with an $\operatorname{sstr}_{5}$ agonist, ACTH secretion is reduced, leading to declines in cortisol secretion from the adrenal glands. This model is supported by evidence from murine AtT20 cells, a corticotroph cell line. Treatment of AtT20 cells with dexamethasone reduced expression of $\operatorname{sstr}_{2}$ mRNA without significantly affecting $\operatorname{sstr}_{5}$ mRNA expression or the ability of an $\operatorname{sstr}_{5}$ agonist to inhibit ACTH secretion [33].

\section{Somatostatin analogs}

\section{Overview}

Generally, somatostatin analogs are designed to emulate the structure of native somatostatins, while lacking the 
enzyme degradation sites of the native molecules. Octreotide and lanreotide (Fig. 2a, b) have long been used for treatment of acromegaly, hyperthyroidism, and gastroenteropancreatic neuroendocrine tumors. Another novel analog, somatoprim (DG3173), selectively binds sstr subtypes 2, 4, and 5 and has demonstrated suppression of growth hormone in octreotide-non-responsive cultured human somatotroph adenomas [34]. However, the clinical utility of somatoprim has not yet been evaluated.

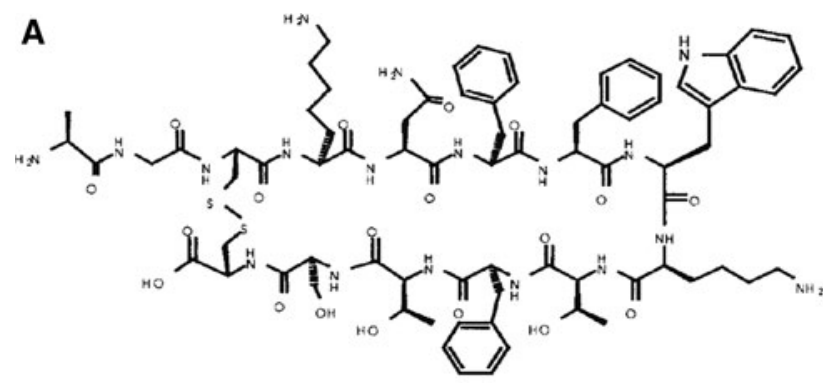

Somatostatin-14

B



Octreotide

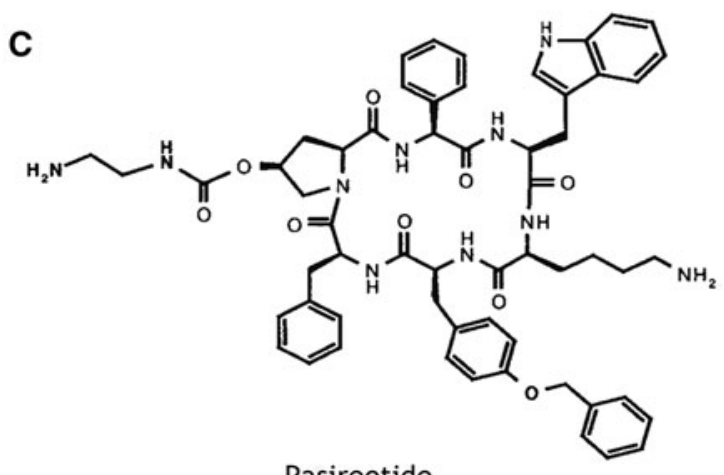

Pasireotide

Fig. 2 Chemical structures of somatostatin-14, octreotide, and pasireotide. Adapted from Bruns C, Lewis I, Briner U, Meno-Tetang G, Weckbecker G (2002) CEuropean Journal of Endocrinology, volume 146, page 710 [38]. Reproduced with permission
Table 1 [35-38] summarizes binding affinities $\left(\mathrm{IC}_{50}\right)$ for somatostatin-14 and for 5 somatostatin analogs. Somatastain-14 binds to all 5 sstrs with similar binding affinity, while both octreotide and lanreotide exhibit relative selectivity for $\operatorname{sstr}_{2}$. This selectivity profile is consistent with studies that have ascribed the efficacy of octreotide and lanreotide at inhibiting growth hormone release from somatotroph adenomas to their activity at $\operatorname{sstr}_{2}$ [39].

\section{Pasireotide}

Overview

Pasireotide is a cyclic hexapeptide that was discovered using a rational approach to design a stable somatostatin analog with a receptor selectivity profile resembling that of native somatostatin. Pasireotide (Fig. 2c), has high affinity for $\operatorname{sstr}_{1,2,3}$ and 5 (Table 1), with much higher affinity for subtypes 1 and 5, and lower affinity for subtype 2, compared with octreotide [40]. In preclinical studies, pasireotide demonstrated inhibition of ACTH secretion in cultured human corticotroph adenomas $[19,20]$ and in murine AtT20 cells [17, 19]; one study has also reported reduced cell proliferation in cultured human corticotropinomas [20]. Compared with octreotide, pasireotide demonstrated greater suppression of CRH-stimulated ACTH release from AtT20cells [17, 19]. Further, consistent with the model of glucocorticoid-mediated downregulation of $\mathrm{sstr}_{2}$, pretreatment of AtT20 cells with dexamethasone abolished the inhibitory effects of octreotide on ACTH secretion, but had no effect on the inhibitory action of pasireotide or somatostatin-14 [33]. Together, these findings support the conclusion that pasireotide inhibits ACTH secretion from corticotroph adenomas by acting predominantly at $\operatorname{sstr}_{5}$. Subsequent supportive in vivo results [41, 42] established the rationale for studies on the use of pasireotide in patients with $\mathrm{CD}$.

Table 1 Binding affinities $\left(\mathrm{IC}_{50}\right)$ for various somatostatin analogs at the 5 known somatostatin receptor subtypes

\begin{tabular}{llllll}
\hline & \multicolumn{5}{c}{ Binding affinity $\left(\mathrm{IC}_{50}\right), \mathrm{nmol} / \mathrm{L}$} \\
\cline { 2 - 6 } Analog & $\mathrm{sstr}_{1}$ & $\mathrm{sstr}_{2}$ & $\mathrm{sstr}_{3}$ & sstr $_{4}$ & $\mathrm{sstr}_{5}$ \\
\hline Somatostatin-14 & 0.93 & 0.15 & 0.56 & 1.5 & 0.29 \\
Octreotide & 280 & 0.38 & 7.1 & $>1000$ & 6.3 \\
Lanreotide & 180 & 0.54 & 14 & 230 & 17 \\
Vapreotide & $>1000$ & 5.4 & 31 & 45 & 0.7 \\
Pasireotide & 9.3 & 1.0 & 1.5 & $>100$ & 0.16 \\
Somatoprim [35] & $>1000$ & 3 & $>100$ & 7 & 6 \\
\hline
\end{tabular}


Clinical trial experience with pasireotide in Cushing's disease

After promising results in a 15-day Phase 2 trial [40], a randomized, double-blind phase 3 trial of pasireotide was conducted in adult patients with de novo, persistent, or recurrent $\mathrm{CD}$ (UFC $\geq 1.5 \times$ upper limit of normal [ULN]) who were not candidates for surgery and with no pituitary radiotherapy in the preceding 10 years. Eligible patients $(N=162)$ were randomized to receive 600 or $900 \mathrm{mcg}$ of pasireotide twice daily for an initial period of 3 months. After 3 months, those with UFC $<$ baseline and $<2 \times$ ULN continued blinded therapy for another 3 months. Other patients were unblinded, and their dose was increased by $300 \mathrm{mcg}$ twice daily. At 6 months, all patients entered the open-label phase of the study and could have their dose increased again to a maximum of $1200 \mathrm{mcg}$ twice daily, if necessary [43].

Figure 3 shows changes from baseline to 6 months in UFC levels for patients in the two dose groups of the phase 3 trial. The majority of patients had declines in UFC levels at 6 months; 6 patients had increases. At 6 months, $15 \%$ of patients in the $600 \mathrm{mcg}$ group and $26 \%$ of patients in the 900 mcg group met the primary endpoint of UFC level within the normal range without dose increase. Median percentage changes in UFC levels from baseline to 6 months were $47.9 \%$ in the $600 \mathrm{mcg}$ group and $-47.9 \%$ in the $900 \mathrm{mcg}$ group. Among the 36 patients who achieved normalization of UFC levels at 6 months, 20 maintained normal levels at 12 months, including some patients who had dose reductions. Moreover, patients who responded to treatment could generally be identified within the first 2 months of treatment [43].

Mean plasma ACTH levels and serum and salivary cortisol levels were reduced at both 6 and 12 months, and patients had significant improvements in signs and symptoms of hypercortisolism during the trial, including reductions in systolic and diastolic blood pressure, triglycerides, low-density lipoprotein cholesterol, and body

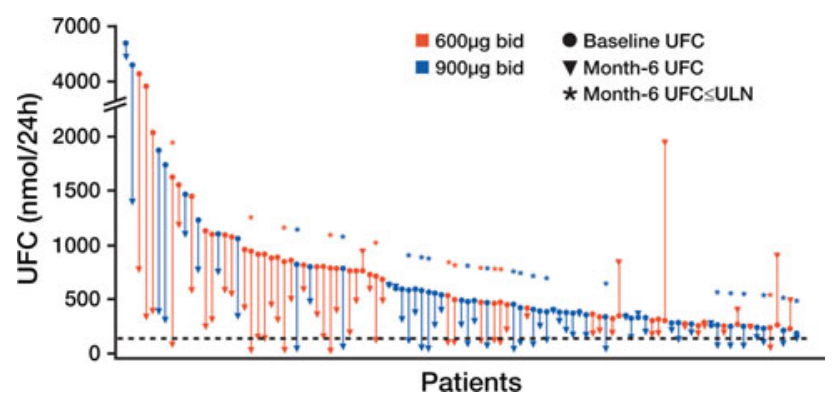

Fig. 3 Changes in UFC levels from baseline to 6 months in individual patients in the phase 3 trial of pasireotide. The dashed black line represents the upper limit of the normal range for UFC. From Colao A, Petersenn S, Newell-Price J, Findling JW, Gu F, Maldonado M, et al., for the Pasireotide B2305 Study Group (2012) N Engl J Med, volume 366, page 918 [43]. Reproduced with permission weight. The time-course of many of these improvements closely followed the time-course UFC reduction. Patients also reported significant increases in health-related quality of life. Finally, among the 75 patients who had measurable pituitary tumors on magnetic resonance images at baseline, tumor volume changed by an average of -9.1 and $-43.8 \%$ in the 600 and 900 mcg groups, respectively [43].

Hyperglycemia-related adverse events occurred in 118 of 162 patients ( $73 \%$ ), and 10 patients discontinued because of such events. Twenty one patients $(13 \%)$ had grade 3 or 4 hyperglycemia, and 74 patients initiated a new antidiabetic medication during the study [43]. While no glycemic intervention studies have been completed in pasireotidetreated CD patients, the mechanism of pasireotide-induced hyperglycemia was investigated in 90 healthy volunteers [44]. Results indicate that pasireotide-induced hyperglycemia is mediated by a reduction in secretion of insulin and incretin hormones glucagon-like peptide-1 (GLP-1) and gastric inhibitory polypeptide (GIP). Glucagon secretion was only mildly inhibited, and pasireotide appears to have no effect on peripheral or hepatic insulin sensitivity in healthy individuals. Treatment with the GLP-1 analog liraglutide or the dipeptidyl peptidase 4 (DPP-4) inhibitor vildagliptin was most effective in countering hyperglycemia in this population, while metformin and nateglinide had little effect.

Patients with CD, however, are often insulin-resistant. A recently published proposal for management of hyperglycemia in patients with $\mathrm{CD}$ treated with pasireotide recommends metformin as first-line medical treatment for CD patients who develop new or worsening hyperglycemia with pasireotide, with an adjunctive DPP-4 inhibitor, sulfonylurea/glinide, and/or GLP-1 analog as required to achieve glycemic control. Metformin plus insulin is recommended if such combination therapy is not tolerated or insufficient and early intervention with insulin is recommended on a case-by-case basis [45].

Other than the degree and severity of hyperglycemiarelated events, the safety and adverse event profiles of pasireotide in the phase 3 trial were similar to those observed with other somatostatin analogs. Other common adverse events were diarrhea (58\%), nausea (52\%), cholelithiasis $(30 \%)$, headache $(28 \%)$, and abdominal pain $(24 \%)$. Among the 137 patients who had a normal gallbladder at baseline, 27 had gallstones at their latest assessment and 6 had a cholecystectomy [43]. Pasireotide was recently approved in the US [46] and Europe [47] for the treatment of adult CD patients for whom pituitary surgery is not an option or has failed.

Dopamine receptors and dopamine receptor agonists

Like somatostatin receptors, dopamine receptors are widely expressed in normal neuro-endocrine tissues and pituitary 
adenomas, including approximately $80 \%$ of corticotroph adenomas $[48,49]$. Five dopamine receptor subtypes have been characterized, usually classified as $\mathrm{D}_{1}$-like or $\mathrm{D}_{2}$-like, with most $\mathrm{D}_{2}$-like receptors associated with inhibitory actions [50]. The dopamine agonists bromocriptine and cabergoline have both been used to treat pituitary adenomas; however, cabergoline is more selective at $\mathrm{D}_{2}$ receptors and has been found to be more effective and better tolerated than bromocriptine in women receiving treatment for hyperprolactinemia [51].

In clinical studies, bromocriptine has had small and variable effects on ACTH secretion in patients with $\mathrm{CD}$ [50]. In contrast, a 2004 study demonstrated significant in vitro inhibition of ACTH secretion with cabergoline in $100 \%$ of cases with confirmed $\mathrm{D}_{2}$ receptor expression, and significant in vivo reduction of cortisol levels in $60 \%$ of cases-with $40 \%$ normalization of cortisol secretion [48]. Altogether, 3 small, non-randomized studies (one with a long-term follow-up publication) have found evidence have found evidence for efficacy of cabergoline in this setting $[48,52,53]$.

In a study of 10 patients, 6 achieved UFC normalization after 3 months' treatment with cabergoline, and 2 additional patients achieved significant UFC reductions [48]. In a follow-up to this investigation, 20 patients were enrolled who had CD unsuccessfully treated by surgery [53]. After 3 months of cabergoline $(1 \mathrm{mg} /$ week with dose adjusted to a maximum of $7 \mathrm{mg} /$ week), 7 patients $(35 \%)$ achieved eucortisolism and an additional $8(40 \%)$ experienced $\geq 25 \%$ decline in UFC. The 8 partial responders all had dose increases, and 6 of these had normal UFC after 6-12 months. However, 5 patients who achieved normal UFC levels either initially or after dose increase escaped from treatment control. Thus, at 12 months, 10 patients (50\%) had normal UFC levels. However, 2 of these patients subsequently discontinued treatment because of severe asthenia, resulting in a long-term control rate of $40 \%$. Most responders exhibited improvements in signs and symptoms of $\mathrm{CD}$, including significant mean declines in blood pressure, waist/hip ratio, serum glucose, and tumor volume, and significant improvements in $\beta$-cell function.

Similar supportive results were found in a retrospective, non-randomized analysis of 30 patients with $\mathrm{CD}$ in Buenos Ares and Montreal who received cabergoline (initially $0.5-1.0 \mathrm{mg} /$ week adjusted to a maximum of $6 \mathrm{mg} /$ week) for up to 5 years [54]. Within 3-6 months, 11 patients (37\%) achieved sustained normalization of UFC ( $\geq 2$ normal values measured at 1-3 months apart; complete response). Nine of these patients achieved long-term UFC normalization after a mean of 37 months (range, 12-60) on a mean cabergoline dose of $2.1 \mathrm{mg} /$ week. Four patients $(13 \%)$ achieved UFC $<125 \%$ ULN (partial response) within 3-6 months of cabergoline initiation, but none of these patients experienced long-term response. Escape from response was observed in 2 patients with long-term complete response after 2 and 5 years of treatment, although one patient transiently renormalized after cabergoline dose increase. Long-term tolerability was positive; no serious adverse events were reported during treatment. No symptoms of cardiovascular dysfunction were reported and no patients presented symptomatic adrenal insufficiency.

Although the results of these small studies have shown promise for the use of cabergoline as medical therapy for $\mathrm{CD}$, no large-scale, double-blind trials have been conducted. Thus, it is difficult to draw conclusions about the overall efficacy and safety of this approach.

One potential concern regarding the use of DA agonists for $\mathrm{CD}$ has been the association of long-term ergot derivatives with increased risk of valvular heart disease [55-57]. However, this risk was identified in studies performed in patients using DA agonists for Parkinson's disease at doses considerably higher (often $>3 \mathrm{mg} /$ day) than those used in $\mathrm{CD}$ (generally $<7 \mathrm{mg} /$ week). Schade et al. [56] reported that the relative risk of valvular heart disease was 50.3 (95\% CI 6.6-381.4) in patients receiving $>3 \mathrm{mg} /$ day compared to 2.6 (95\% CI $0.5-12.8$ ) in patients receiving $<3 \mathrm{mg} /$ day. Furthermore, a study of 78 patients receiving DA agonists (including 47 who were using cabergoline) for an average of 8 years for prolactinoma found an increased risk of aortic valve calcification and mild tricuspid regurgitation, but no increase in the risk of clinically relevant valvular heart disease compared to control patients [58]. Among patients receiving cabergoline, the mean duration of therapy was $5.2 \pm 0.4$ years and the mean cumulative dose was $363 \pm 55 \mathrm{mg}$. There was no relation between cumulative dose of cabergoline and the presence of mild, moderate or severe valve regurgitation. Thus, the evidence suggests that valvular heart disease associated with long-term use of DA agonists is much less of a concern for patients using the doses typical of treatment regimens for $\mathrm{CD}$. A summary of current prospective studies with pituitary targeted medical therapy is provided in Table 2 [40, 43, 48, 52, 53, 59].

\section{Other investigational therapies}

Combination somatostatin analog-dopamine agonist

Combined use of a somatostatin analog and a dopamine agonist for treatment of $\mathrm{CD}$ has been proposed on the basis of similar studies suggesting additive effects on growth hormone secretion from somatotroph adenomas [60]. In a study of 17 patients with CD, pasireotide monotherapy (100-250 mcg three times a day) normalized UFC levels in 5 patients, and addition of cabergoline (0.5-1.5 mg every other day) normalized UFC levels 
Table 2 Medical treatments for Cushing's disease evaluated in prospective clinical studies

\begin{tabular}{|c|c|c|c|c|}
\hline Compound & Trial & Patients $(N)$ & $\begin{array}{l}\text { Treatment } \\
\text { duration }\end{array}$ & Outcome \\
\hline \multirow[t]{2}{*}{ Pasireotide } & Boscaro et al. [40] & 29 & 15 days & $\begin{array}{l}5 / 29 \text { patients }(17 \%) \text { achieved UFC } \leq \text { ULN; } 22 / 29 \text { patients } \\
(76 \%) \text { experienced reduction in mean UFC }\end{array}$ \\
\hline & Colao et al. [43] & 162 & 12 months & $\begin{array}{l}33 / 162 \text { patients }(20 \%) \text { achieved UFC } \leq \text { ULN within } \\
6 \text { months without increase from randomized dose; the } \\
\text { majority of patients experienced reduction in UFC at month } \\
6 \text {, sustained through month } 12\end{array}$ \\
\hline \multirow[t]{2}{*}{ Cabergoline } & Lila et al. [52] & 18 & 5 months & $\begin{array}{l}5 \text { patients }(28 \%) \text { achieved MNSC }<5 \mu \mathrm{g} / \mathrm{dL} \text { or low-dose } \\
\text { dexamethasone-suppressed serum cortisol }<1.8 \mu \mathrm{g} / \mathrm{dL}\end{array}$ \\
\hline & Pivonello et al. [48, 53] & 20 & $3-24$ months & $\begin{array}{l}\text { After } 3 \text { months, } 15 \text { patients }(75 \%) \text { achieved UFC } \leq \text { ULN or } \\
\geq 25 \% \text { reduction from baseline; } 8 \text { patients }(40 \%) \\
\text { maintained UFC } \leq \text { ULN at } 24 \text { months }\end{array}$ \\
\hline Retinoic acid & Pecori Girald et al. [59] & 7 & $6-12$ months & $\begin{array}{l}3 / 7 \text { patients }(43 \%) \text { achieved UFC } \leq \text { ULN; } 5 / 7 \text { patients }(71 \%) \\
\text { experienced reduction in UFC }\end{array}$ \\
\hline
\end{tabular}

MNSC midnight salivary cortisol, $U F C$ urinary free cortisol, $U L N$ upper limit of normal

in 4 more patients. Among the remaining 8 patients, subsequent addition of ketoconazole ( $200 \mathrm{mg}$ three times a day) normalized UFC levels in 6 , leaving only 2 patients who still had elevated UFC levels. Thus, sequential therapy using these three agents shows promise but requires further studies of both efficacy and safety [61].

Temozolomide monotherapy and in combination

Temozolomide, an oral alkylating agent typically used in chemotherapeutic treatment of astrocytoma and melanoma, has shown promise as monotherapy [62, 63], and in combination with pasireotide [64], as a treatment for aggressive pituitary adenomas and carcinomas.

To date, $\sim 30$ cases of pituitary adenoma have been treated with temozolomide (including ten ACTH-secreting adenomas). Overall reported response rate is approximately $60 \%$ [62, 63]; however, information on temozolomide treatment of pituitary adenomas is currently confined to individual case reports and three case series [65-67]. An inverse relationship between tumoral $\mathrm{O}^{6}$-methylguanineDNA methyltransferase (MGMT) immunoexpression and response to temozolomide therapy has been suggested, but not confirmed in all studies [62, 65, 67, 68].

Temozolomide may represent a viable treatment option for aggressive corticotroph adenomas refractory to surgery, radiotherapy, or other medical treatment. In tumors that responded to temozolomide, the clinical response was associated with prompt reductions in ACTH, chiasmatic compression and mass effects. Thus, it is possible to evaluate response early in the course of treatment. Targeted modulation of MGMT expression may be useful in patients who may otherwise not respond to temozolomide therapy [63].

\section{Retinoic acid}

The retinoic acid receptor is a type II nuclear receptor involved with transcriptional regulation. In a murine corticotrope tumor cell line, retinoic acid has been shown to reduce $\mathrm{ACTH}$ secretion and pro-opiomelanocortin (POMC) synthesis. Further, there is evidence that, with prolonged treatment, retinoic acid induces increased caspase- 3 activity and cell death in ACTH-secreting cells. It has also demonstrated inhibition of corticosterone production and cell proliferation in adrenal cortex cells [69]. Retinoic acid had demonstrated reduced ACTH secretion and prevented tumor growth in mice with implanted with tumoral corticotropes [70]. In a 6-month study in dogs with spontaneous corticotrope tumors, retinoic acid reduced cortisol excess and improved associated symptoms [71].

A recent small study showed a marked reduction in UFC levels in 5/7 patients (22-73\% of baseline values), and UFC normalization in three patients. There was no apparent pattern of decrease in plasma cortisol. Plasma ACTH decreased in the first month of treatment and then returned to pretreatment levels in responsive patients. Blood pressure, glycemia, and signs of hypercortisolism improved on treatment. Patients reported only mild adverse effects (e.g., xerophthalmia and arthralgias) [59].

\section{EGFR}

The epidermal growth factor receptor (EGFR) family has recently been studied as a therapeutic target for $\mathrm{CD}$. In cultured human and canine corticotroph tumors, gefitinib (an EGFR tyrosine kinase inhibitor) attenuated POMC expression, inhibited corticotroph tumor cell proliferation, and 
Fig. 4 Potential targets and medical therapies in Cushing's disease. From Fleseriu, M (2012) Neurosurg Clin N Am volume 23, page 657 [85]. Reproduced with permission
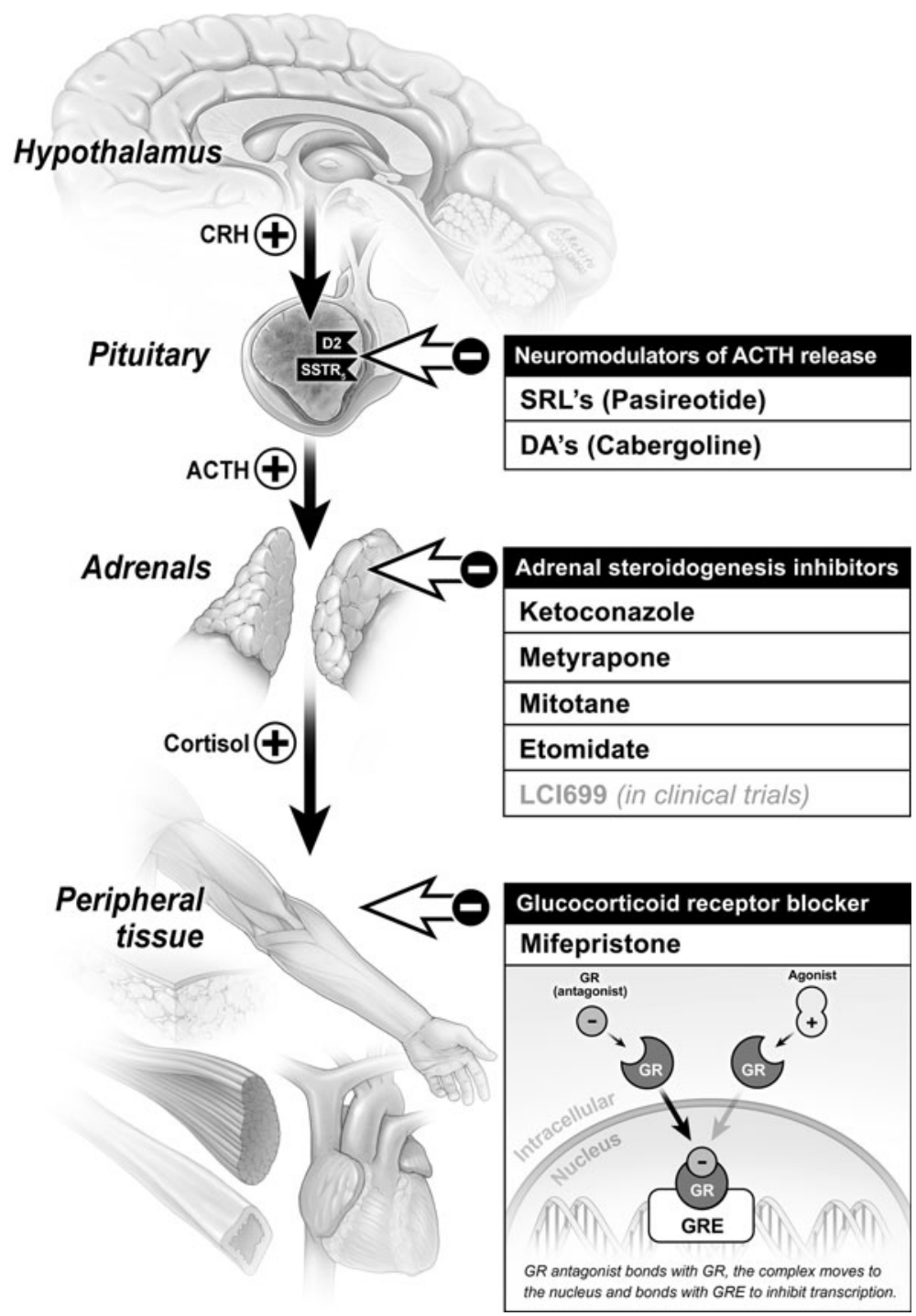

induced apoptosis. In murine studies, gefitinib decreased tumor size and corticosterone levels, and reversed signs of hypercortisolemia, including elevated glucose levels and excess omental fat [72]. These results indicate that inhibiting EGFR signaling may be a valuable strategy for treating CD. Further studies evaluating clinical efficacy and safety in patients with $\mathrm{CD}$ are needed.

\section{Doxazosin}

The selective alpha(1)-adrenergic receptor antagonist, doxazosin has been shown to decrease plasma ACTH and inhibit proliferation in human and murine pituitary tumor cells, and may represent a potentially useful treatment option in pituitary adenomas [73]. However, there is currently no clinical experience with doxazosin, and more data are required before any such treatment strategy could be advocated.

\section{Other medical treatment modalities in Cushing's disease}

Mifepristone: glucocorticoid receptor blockade

Mifepristone is a glucocorticoid receptor (GR2) antagonist, recently FDA-approved to treat hyperglycemia in adult patients with Cushing's syndrome who have failed surgery or are not surgical candidates. Regulatory approval was based on a 24-week open-label trial studying 50 Cushing's patients (43 with CD) and associated type 2 diabetes mellitus/impaired glucose tolerance (DM/IGT), or hypertension [74]. At the end of the treatment period, 15/25 patients $(60 \%)$ in the DM/IGT group achieved $\geq 25 \%$ reductions in glucose $\mathrm{AUC}_{0-120 \mathrm{~min}}$. Patients also exhibited reductions in $\mathrm{HbA}_{1 \mathrm{c}}$ and fasting plasma glucose levels, as well as reduced body weight and waist circumference, improvements in clinical status and quality of life. 
With GR2 receptor blockade, ACTH and cortisol will likely increase, potentially resulting in hypokalemia, increased blood pressure, edema, or alkalosis through activation of mineralocorticoid receptors [75]. Other potential adverse reactions include adrenal insufficiency (AI) and endometrial thickening with vaginal bleedingboth requiring close monitoring and treatment [76, 77]. As there is no biochemical marker to follow (cortisol values are not reliable), treatment efficacy and potential adrenal insufficiency must be gauged through changes in clinical signs and symptoms [77]. Mifepristone is also a potent antagonist of progesterone, thus premenopausal women must be tested for pregnancy before administration. Caution is also warranted in combination with drugs metabolized by CYP3A or CYP2C (e.g., simvastatin, cyclosporine, fentanyl, ciprofloxacin, NSAIDs, warfarin).

\section{Adrenal-targeted drugs}

Drugs inhibiting adrenocortical steroidogenesis include ketoconazole, mitotane, etomidate and metyrapone. In general, use of these drugs requires careful clinical monitoring for adverse effects, including AI [77]. Ketoconazole has been widely used to treat CD because it inhibits several steps in adrenal steroid synthesis and reduces UFC in the majority of patients with CD [78]. However, it also inhibits androgen synthesis and is associated with liver toxicity in some patients [79]. There is little prospective information on the long-term use of adrenal-targeted agents [11, 80]; however, 1 small retrospective study showed promising results [81, 82]. Mitotane also inhibits several steps in steroidogenesis, and can be adrenolytic during long-term therapy at doses $>4 \mathrm{~g} /$ day [77]. Because mitotane is sequestered in adipose tissue and eliminated slowly, pregnancy must be avoided for 5 years after discontinuation [77].

LCI699 is a novel inhibitor of $11 \beta$-hydroxylase (the final enzyme in the cortisol synthesis pathway) under development for several indications, including CD. In a recent proof-of-concept study in patients with CD (UFC $>1.5 \times \mathrm{ULN})$, all participants $(N=12)$ achieved either UFC normalization or $\geq 50 \%$ reduction from baseline after 70 days of treatment. While all patients experienced $\geq 1$ AE, most were mild or moderate. Some AEs consistent with AI were reported, and resolved after dose reduction. Four patients experienced hypokalemia; all cases were managed without dose reduction, and 3 patients received oral potassium supplementation [83]. A larger-scale, 22-week expansion trial is currently underway [84]. A summary of potential therapeutic targets in CD is shown in Fig. 4 [85].

\section{Conclusions and future directions}

Medical therapies targeting the corticotroph adenoma represent a relatively new avenue in the long term treatment of patients with CD who are unsuitable for surgery, or who fail to achieve long-term disease control post-surgery [86, 87]. Drugs targeting adrenal steroid synthesis have been in use for many years, but have not been prospectively studied and do not target the underlying pituitary tumor. A glucocorticoid receptor blocker could be a valuable asset in selected patients, but is relatively complicated to use due to absence of a biochemical marker, and there are potential adverse reactions inherent to mechanism of action.

Pasireotide, a multiligand somatostatin analog is the first pituitary-directed agent shown to effectively reduce cortisol levels and improve disease symptoms in a large, prospective, phase 3 clinical trial. Further investigation is needed, however, to clarify optimal management approaches for pasireotide-associated hyperglycemia. The dopamine agonist cabergoline has shown some promise in a small, open-label trial (and one retrospective trial), but randomized, controlled trials with this agent have not been conducted. A combination of lower doses of pasireotide with dopamine agonists or adrenal steroidogenesis inhibitors (e.g., a combination of low-dose pasireotide/cabergoline/ketoconazole) may increase the proportion of patients whose disease can be controlled while minimizing adverse effects.

Finally, further research into patterns of receptor expression in corticotroph adenomas may lead to increased understanding of the pathogenesis of these tumors, and allow development of therapies specifically tailored to individual patients following analysis of surgical pathology.

Acknowledgments The authors would like to thank Ken Scholz, $\mathrm{PhD}$, Shirley McCartney, PhD, and David Wolff, MS, for editorial assistance with this manuscript.

Conflict of interest Dr. Fleseriu has received consultant fees from Novartis Pharmaceuticals and Ipsen, and is a principal investigator in clinical trials sponsored by Novartis Pharmaceuticals, Corcept Therapeutics, and Ipsen, with research support to OHSU. Dr. Petersenn has received consultant fees from Novartis Pharmaceuticals, Pfizer and Ipsen, and is a principal investigator in clinical trials sponsored by Novartis Pharmaceuticals and Ipsen. Partial financial support (Ken Scholtz and David Wolff) has been provided by Novartis Pharmaceuticals. The authors are solely responsible for all content.

Open Access This article is distributed under the terms of the Creative Commons Attribution License which permits any use, distribution, and reproduction in any medium, provided the original author(s) and the source are credited.

\section{References}

1. Etxabe J, Vazquez JA (1994) Morbidity and mortality in Cushing's disease: an epidemiological approach. Clin Endocrinol (Oxf) 40:479-484 
2. Newell-Price J, Bertagna X, Grossman AB, Nieman LK (2006) Cushing's syndrome. Lancet 367:1605-1617. doi:10.1016/S01406736(06)68699-6

3. Steffensen C, Bak AM, Rubeck KZ, Jorgensen JO (2010) Epidemiology of Cushing's syndrome. Neuroendocrinology 92(Suppl 1): 1-5. doi:10.1159/000314297

4. Melmed S, Kleinberg D, Ho K (2011) Pituitary physiology and diagnostic evaluation. In: Melmed S, Polonsky K, Larsen P, Kronenberg H (eds) Williams textbook of endocrinology, 12th edn. Elsevier, Philadelphia

5. Krieger DT, Allen W (1975) Relationship of bioassayable and immunoassayable plasma ACTH and cortisol concentrations in normal subjects and in patients with Cushing's disease. J Clin Endocrinol Metab 40:675-687

6. Liu JH, Kazer RR, Rasmussen DD (1987) Characterization of the twenty-four hour secretion patterns of adrenocorticotropin and cortisol in normal women and patients with Cushing's disease. J Clin Endocrinol Metab 64:1027-1035

7. Roelfsema F, Pincus SM, Veldhuis JD (1998) Patients with Cushing's disease secrete adrenocorticotropin and cortisol jointly more asynchronously than healthy subjects. J Clin Endocrinol Metab 83:688-692

8. Boyar RM, Witkin M, Carruth A, Ramsey J (1979) Circadian cortisol secretory rhythms in Cushing's disease. J Clin Endocrinol Metab 48:760-765

9. Tourniaire J, Chalendar D, Rebattu B, Fevre-Montange M, Bajard L, Mazenod B, Dechaud H, Abou Samra AB, van Cauter E (1986) The 24-h cortisol secretory pattern in Cushing's syndrome. Acta Endocrinol (Copenh) 112:230-237

10. van den Berg G, Pincus SM, Veldhuis JD, Frolich M, Roelfsema F (1997) Greater disorderliness of ACTH and cortisol release accompanies pituitary-dependent Cushing's disease. Eur J Endocrinol 136:394-400

11. Biller BM, Grossman AB, Stewart PM, Melmed S, Bertagna X, Bertherat J, Buchfelder M, Colao A, Hermus AR, Hofland LJ, Klibanski A, Lacroix A, Lindsay JR, Newell-Price J, Nieman LK, Petersenn S, Sonino N, Stalla GK, Swearingen B, Vance ML, Wass JA, Boscaro M (2008) Treatment of adrenocorticotropindependent Cushing's syndrome: a consensus statement. J Clin Endocrinol Metab 93:2454-2462. doi:10.1210/jc.2007-2734

12. Atkinson AB, Kennedy A, Wiggam MI, McCance DR, Sheridan B (2005) Long-term remission rates after pituitary surgery for Cushing's disease: the need for long-term surveillance. Clin Endocrinol (Oxf) 63:549-559. doi:10.1111/j.1365-2265.2005. 02380.x

13. Patil CG, Prevedello DM, Lad SP, Vance ML, Thorner MO, Katznelson L, Laws ER Jr (2008) Late recurrences of Cushing's disease after initial successful transsphenoidal surgery. J Clin Endocrinol Metab 93:358-362. doi:10.1210/jc.2007-2013

14. Patel YC (1999) Somatostatin and its receptor family. Front Neuroendocrinol 20:157-198. doi:10.1006/frne.1999.0183

15. Bruno JF, Xu Y, Song J, Berelowitz M (1993) Tissue distribution of somatostatin receptor subtype messenger ribonucleic acid in the rat. Endocrinology 133:2561-2567

16. O'Carroll AM (2003) Localization of messenger ribonucleic acids for somatostatin receptor subtypes (sstr1-5) in the rat adrenal gland. J Histochem Cytochem 51:55-60

17. Hofland LJ, Lamberts SW (2004) Somatostatin receptors in pituitary function, diagnosis and therapy. Front Horm Res 32: 235-252

18. Unger N, Ueberberg B, Schulz S, Saeger W, Mann K, Petersenn S (2012) Differential expression of somatostatin receptor subtype 1-5 proteins in numerous human normal tissues. Exp Clin Endocrinol Diabetes 120:482-489. doi:10.1055/s-0032-1314859

19. Hofland LJ, van der Hoek J, Feelders R, van Aken MO, van Koetsveld PM, Waaijers M, Sprij-Mooij D, Bruns C, Weckbecker
G, de Herder WW, Beckers A, Lamberts SW (2005) The multiligand somatostatin analogue SOM230 inhibits ACTH secretion by cultured human corticotroph adenomas via somatostatin receptor type 5. Eur J Endocrinol 152:645-654. doi:10.1530/eje.1. 01876

20. Batista DL, Zhang X, Gejman R, Ansell PJ, Zhou Y, Johnson SA, Swearingen B, Hedley-Whyte ET, Stratakis CA, Klibanski A (2006) The effects of SOM230 on cell proliferation and adrenocorticotropin secretion in human corticotroph pituitary adenomas. J Clin Endocrinol Metab 91:4482-4488. doi:10.1210/jc.2006-1245

21. Voight KH, Fehm HL, Lang RE, Walter R (1977) The effect of somatostatin and of prolyl-leucyl-glycinamide (MIF) on ACTH release in dispersed pituitary cells. Life Sci 21:739-745

22. Fehm HL, Voigt KH, Lang R, Beinert KE, Raptis S, Pfeiffer EF (1976) Somatostatin: a potent inhibitor of ACTH-hypersecretion in adrenal insufficiency. Klin Wochenschr 54:173-175

23. Lamberts SW, Uitterlinden P, Klijn JM (1989) The effect of the long-acting somatostatin analogue SMS 201-995 on ACTH secretion in Nelson's syndrome and Cushing's disease. Acta Endocrinol (Copenh) 120:760-766

24. Tyrrell JB, Lorenzi M, Gerich JE, Forsham PH (1975) Inhibition by somatostatin of ACTH secretion in Nelson's syndrome. J Clin Endocrinol Metab 40:1125-1127

25. Brown MR, Rivier C, Vale W (1984) Central nervous system regulation of adrenocorticotropin secretion: role of somatostatins. Endocrinology 114:1546-1549

26. Kraicer J, Gajewski TC, Moor BC (1985) Release of pro-opiomelanocortin-derived peptides from the pars intermedia and pars distalis of the rat pituitary: effect of corticotrophin-releasing factor and somatostatin. Neuroendocrinology 41:363-373

27. Ambrosi B, Bochicchio D, Fadin C, Colombo P, Faglia G (1990) Failure of somatostatin and octreotide to acutely affect the hypothalamic-pituitary-adrenal function in patients with corticotropin hypersecretion. J Endocrinol Invest 13:257-261

28. de Herder WW, van der Lely AJ, Lamberts SW (1996) Somatostatin analogue treatment of neuroendocrine tumours. Postgrad Med J 72:403-408

29. Invitti C, de Martin M, Brunani A, Piolini M, Cavagnini F (1990) Treatment of Cushing's syndrome with the long-acting somatostatin analogue SMS 201-995 (sandostatin). Clin Endocrinol (Oxf) 32:275-281

30. Stalla GK, Brockmeier SJ, Renner U, Newton C, Buchfelder M, Stalla J, Muller OA (1994) Octreotide exerts different effects in vivo and in vitro in Cushing's disease. Eur J Endocrinol 130:125-131

31. Hofland LJ (2008) Somatostatin and somatostatin receptors in Cushing's disease. Mol Cell Endocrinol 286:199-205. doi: 10.1016/j.mce.2007.10.015

32. van der Hoek J, Lamberts SW, Hofland LJ (2007) Preclinical and clinical experiences with the role of somatostatin receptors in the treatment of pituitary adenomas. Eur J Endocrinol 156(Suppl 1):S45-S51. doi:10.1530/eje.1.02350

33. van der Hoek J, Waaijers M, van Koetsveld PM, Sprij-Mooij D, Feelders RA, Schmid HA, Schoeffter P, Hoyer D, Cervia D, Taylor JE, Culler MD, Lamberts SW, Hofland LJ (2005) Distinct functional properties of native somatostatin receptor subtype 5 compared with subtype 2 in the regulation of ACTH release by corticotroph tumor cells. Am J Physiol Endocrinol Metab 289:E278-E287. doi:10.1152/ajpendo.00004.2005

34. Plockinger U, Hoffmann U, Geese M, Lupp A, Buchfelder M, Flitsch J, Vajkoczy P, Jakob W, Saeger W, Schulz S, Dohrmann C (2012) DG3173 (somatoprim), a unique somatostatin receptor subtypes 2-, 4and 5-selective analogue, effectively reduces $\mathrm{GH}$ secretion in human GH-secreting pituitary adenomas even in Octreotide non-responsive tumours. Eur J Endocrinol 166:223-234. doi:10.1530/EJE-11-0737

35. Afargan M, Janson ET, Gelerman G, Rosenfeld R, Ziv O, Karpov O, Wolf A, Bracha M, Shohat D, Liapakis G, Gilon C, Hoffman 
A, Stephensky D, Oberg K (2001) Novel long-acting somatostatin analog with endocrine selectivity: potent suppression of growth hormone but not of insulin. Endocrinology 142:477-486

36. Susini C, Buscail L (2006) Rationale for the use of somatostatin analogs as antitumor agents. Ann Oncol 17:1733-1742. doi: 10.1093/annonc/mdl105

37. Weckbecker G, Lewis I, Albert R, Schmid HA, Hoyer D, Bruns C (2003) Opportunities in somatostatin research: biological, chemical and therapeutic aspects. Nat Rev Drug Discov 2:999-1017. doi: 10.1038/nrd1255

38. Bruns C, Lewis I, Briner U, Meno-Tetang G, Weckbecker G (2002) SOM230: a novel somatostatin peptidomimetic with broad somatotropin release inhibiting factor (SRIF) receptor binding and a unique antisecretory profile. Eur J Endocrinol 146:707-716

39. Murray RD, Melmed S (2008) A critical analysis of clinically available somatostatin analog formulations for therapy of acromegaly. J Clin Endocrinol Metab 93:2957-2968. doi:10.1210/jc. 2008-0027

40. Boscaro M, Ludlam WH, Atkinson B, Glusman JE, Petersenn S, Reincke M, Snyder P, Tabarin A, Biller BM, Findling J, Melmed S, Darby CH, Hu K, Wang Y, Freda PU, Grossman AB, Frohman LA, Bertherat J (2009) Treatment of pituitary-dependent Cushing's disease with the multireceptor ligand somatostatin analog pasireotide (SOM230): a multicenter, phase II trial. J Clin Endocrinol Metab 94:115-122. doi:10.1210/jc.2008-1008

41. Castillo V, Theodoropoulou M, Stalla J, Gallelli MF, CabreraBlatter MF, Haedo MR, Labeur M, Schmid HA, Stalla GK, Arzt E (2011) Effect of SOM230 (pasireotide) on corticotropic cells: action in dogs with Cushing's disease. Neuroendocrinology 94:124-136. doi:10.1159/000327429

42. Silva AP, Schoeffter P, Weckbecker G, Bruns C, Schmid HA (2005) Regulation of CRH-induced secretion of ACTH and corticosterone by SOM230 in rats. Eur J Endocrinol 153:R7-R10. doi:10.1530/eje.1.01998

43. Colao A, Petersenn S, Newell-Price J, Findling JW, Gu F, Maldonado M, Schoenherr U, Mills D, Salgado LR, Biller BM (2012) A 12-month phase 3 study of pasireotide in Cushing's disease. N Engl J Med 366:914-924. doi:10.1056/NEJMoa1105743

44. Henry R, Mudaliar S, Hermosillo Reséndiz K, Ligueros-Saylan M, Chenji S, Golor G (2011) Mechanism and management of hyperglycemia associated with pasireotide: results from studies in healthy volunteers. Endocr Rev 32:P3-P274

45. Reznik Y, Bertherat J, Borson-Chazot F, Brue T, Chanson P, Cortet-Rudelli C, Delemer B, Tabarin A, Bisot-Locard S, Verges B (2012) Management of hyperglycaemia in Cushing's disease: experts' proposals on the use of pasireotide. Diabetes Metab. doi: 10.1016/j.diabet.2012.10.005

46. Novartis (2012) Signifor full US prescribing information. http://www.pharma.us.novartis.com/cs/www.pharma.us.novartis. com/product/pi/pdf/signifor.pdf. Accessed 21 Feb 2013

47. Novartis (2012) Signifor EU SPC. http://www.signifor.com/european-product-characteristics.jsp. Accessed $21 \mathrm{Feb} 2013$

48. Pivonello R, Ferone D, de Herder WW, Kros JM, De Caro ML, Arvigo M, Annunziato L, Lombardi G, Colao A, Hofland LJ, Lamberts SW (2004) Dopamine receptor expression and function in corticotroph pituitary tumors. J Clin Endocrinol Metab 89: 2452-2462

49. Stefaneanu L, Kovacs K, Horvath E, Buchfelder M, Fahlbusch R, Lancranjan L (2001) Dopamine D2 receptor gene expression in human adenohypophysial adenomas. Endocrine 14:329-336

50. de Bruin C, Feelders RA, Lamberts SW, Hofland LJ (2009) Somatostatin and dopamine receptors as targets for medical treatment of Cushing's syndrome. Rev Endocr Metab Disord 10:91-102. doi:10.1007/s11154-008-9082-4

51. Colao A, Lombardi G, Annunziato L (2000) Cabergoline. Expert Opin Pharmacother 1:555-574. doi:10.1517/14656566.1.3.555
52. Lila AR, Gopal RA, Acharya SV, George J, Sarathi V, Bandgar T, Menon PS, Shah NS (2010) Efficacy of cabergoline in uncured (persistent or recurrent) Cushing disease after pituitary surgical treatment with or without radiotherapy. Endocr Pract 16: 968-976. doi:10.4158/ep10031.or

53. Pivonello R, De Martino MC, Cappabianca P, De Leo M, Faggiano A, Lombardi G, Hofland LJ, Lamberts SW, Colao A (2009) The medical treatment of Cushing's disease: effectiveness of chronic treatment with the dopamine agonist cabergoline in patients unsuccessfully treated by surgery. J Clin Endocrinol Metab 94:223-230. doi:10.1210/jc.2008-1533

54. Godbout A, Manavela M, Danilowicz K, Beauregard H, Bruno OD, Lacroix A (2010) Cabergoline monotherapy in the long-term treatment of Cushing's disease. Eur J Endocrinol 163:709-716. doi:10.1530/EJE-10-0382

55. Rasmussen VG, Poulsen SH, Dupont E, Ostergaard K, Safikhany G, Egeblad H (2008) Heart valve disease associated with treatment with ergot-derived dopamine agonists: a clinical and echocardiographic study of patients with Parkinson's disease. J Intern Med 263:90-98. doi:10.1111/j.1365-2796.2007.01874.x

56. Schade R, Andersohn F, Suissa S, Haverkamp W, Garbe E (2007) Dopamine agonists and the risk of cardiac-valve regurgitation. N Engl J Med 356:29-38. doi:10.1056/NEJMoa062222

57. Simonis G, Fuhrmann JT, Strasser RH (2007) Meta-analysis of heart valve abnormalities in Parkinson's disease patients treated with dopamine agonists. Mov Disord 22:1936-1942. doi: $10.1002 /$ mds. 21639

58. Kars M, Delgado V, Holman ER, Feelders RA, Smit JW, Romijn JA, Bax JJ, Pereira AM (2008) Aortic valve calcification and mild tricuspid regurgitation but no clinical heart disease after 8 years of dopamine agonist therapy for prolactinoma. J Clin Endocrinol Metab 93:3348-3356. doi:10.1210/jc.2007-2658

59. Pecori Giraldi F, Ambrogio AG, Andrioli M, Sanguin F, Karamouzis I, Corsello SM, Scaroni C, Arvat E, Pontercorvi A, Cavagnini F (2012) Potential role for retinoic acid in patients with Cushing's disease. J Clin Endocrinol Metab 97:3577-3583. doi:10.1210/jc.2012-2328

60. Colao A, Filippella M, Pivonello R, Di Somma C, Faggiano A, Lombardi G (2007) Combined therapy of somatostatin analogues and dopamine agonists in the treatment of pituitary tumours. Eur J Endocrinol 156(Suppl 1):S57-S63. doi:10.1530/eje.1.02348

61. Feelders RA, de Bruin C, Pereira AM, Romijn JA, Netea-Maier RT, Hermus AR, Zelissen PM, van Heerebeek R, de Jong FH, van der Lely AJ, de Herder WW, Hofland LJ, Lamberts SW (2010) Pasireotide alone or with cabergoline and ketoconazole in Cushing's disease. N Engl J Med 362:1846-1848. doi:10.1056/NEJMc1000094

62. Dillard TH, Gultekin SH, Delashaw JB Jr, Yedinak CG, Neuwelt EA, Fleseriu M (2011) Temozolomide for corticotroph pituitary adenomas refractory to standard therapy. Pituitary 14:80-91. doi: 10.1007/s11102-010-0264-1

63. Ortiz LD, Syro LV, Scheithauer BW, Rotondo F, Uribe H, Fadul CE, Horvath E, Kovacs K (2012) Temozolomide in aggressive pituitary adenomas and carcinomas. Clinics (Sao Paulo) 67(Suppl 1):119-123

64. Bode H, Seiz M, Lammert A, Brockmann MA, Back W, Hammes HP, Thome C (2010) SOM230 (pasireotide) and temozolomide achieve sustained control of tumour progression and ACTH secretion in pituitary carcinoma with widespread metastases. Exp Clin Endocrinol Diabetes 118:760-763. doi:10.1055/s-00301253419

65. Bush ZM, Longtine JA, Cunningham T, Schiff D, Jane JA Jr, Vance ML, Thorner MO, Laws ER Jr, Lopes MB (2010) Temozolomide treatment for aggressive pituitary tumors: correlation of clinical outcome with $\mathrm{O}(6)$-methylguanine methyltransferase (MGMT) promoter methylation and expression. J Clin Endocrinol Metab 95:E280-E290. doi:10.1210/jc.2010-0441 
66. Losa M, Mazza E, Terreni MR, McCormack A, Gill AJ, Motta M, Cangi MG, Talarico A, Mortini P, Reni M (2010) Salvage therapy with temozolomide in patients with aggressive or metastatic pituitary adenomas: experience in six cases. Eur $\mathrm{J}$ Endocrinol 163:843-851. doi:10.1530/EJE-10-0629

67. Raverot G, Sturm N, de Fraipont F, Muller M, Salenave S, Caron P, Chabre O, Chanson P, Cortet-Rudelli C, Assaker R, Dufour H, Gaillard S, Francois P, Jouanneau E, Passagia JG, Bernier M, Cornelius A, Figarella-Branger D, Trouillas J, Borson-Chazot F, Brue $T$ (2010) Temozolomide treatment in aggressive pituitary tumors and pituitary carcinomas: a French multicenter experience. J Clin Endocrinol Metab 95:4592-4599. doi:10.1210/jc.2010-0644

68. Kovacs K, Scheithauer BW, Lombardero M, McLendon RE, Syro LV, Uribe H, Ortiz LD, Penagos LC (2008) MGMT immunoexpression predicts responsiveness of pituitary tumors to temozolomide therapy. Acta Neuropathol (Berl) 115:261-262. doi: 10.1007/s00401-007-0279-5

69. Paez-Pereda M, Kovalovsky D, Hopfner U, Theodoropoulou M, Pagotto U, Uhl E, Losa M, Stalla J, Grubler Y, Missale C, Arzt E, Stalla GK (2001) Retinoic acid prevents experimental Cushing syndrome. J Clin Invest 108:1123-1131. doi:10.1172/JCI11098

70. Giacomini D, Paez-Pereda M, Theodoropoulou M, Labeur M, Refojo D, Gerez J, Chervin A, Berner S, Losa M, Buchfelder M, Renner U, Stalla GK, Arzt E (2006) Bone morphogenetic protein-4 inhibits corticotroph tumor cells: involvement in the retinoic acid inhibitory action. Endocrinology 147:247-256. doi:10.1210/en.2005-0958

71. Castillo V, Giacomini D, Páez-Pereda M, Stalla J, Labeur M, Theodoropoulou M, Holsboer F, Grossman AB, Stalla GK, Arzt E (2006) Retinoic acid as a novel medical therapy for Cushing's disease in dogs. Endocrinology 147:4438-4444. doi:10.1210/en.2006-0414

72. Fukuoka H, Cooper O, Ben-Shlomo A, Mamelak A, Ren S-G, Bruyette D, Melmed S (2011) EGFR as a therapeutic target for human, canine, and mouse ACTH-secreting pituitary adenomas. J Clin Invest 121:4712-4721. doi:10.1172/jci60417

73. Fernando MA, Heaney AP (2005) Alpha1-adrenergic receptor antagonists: novel therapy for pituitary adenomas. Mol Endocrinol 19:3085-3096. doi:10.1210/me.2004-0471

74. Fleseriu M, Biller BM, Findling JW, Molitch ME, Schteingart DE, Gross C (2012) Mifepristone, a glucocorticoid receptor antagonist, produces clinical and metabolic benefits in patients with Cushing's syndrome. J Clin Endocrinol Metab 97:2039-2049. doi:10.1210/jc. 2011-3350

75. van Uum SH, Lenders JW, Hermus AR (2004) Cortisol, 11 betahydroxysteroid dehydrogenases, and hypertension. Semin Vasc Med 4:121-128. doi:10.1055/s-2004-835369
76. Castinetti F, Fassnacht M, Johanssen S, Terzolo M, Bouchard P, Chanson P, Do Cao C, Morange I, Pico A, Ouzounian S, Young J, Hahner S, Brue T, Allolio B, Conte-Devolx B (2009) Merits and pitfalls of mifepristone in Cushing's syndrome. Eur J Endocrinol 160:1003-1010. doi:10.1530/EJE-09-0098

77. Tritos NA, Biller BM (2012) Advances in medical therapies for Cushing's syndrome. Discov Med 13:171-179

78. Engelhardt D, Weber MM (1994) Therapy of Cushing's syndrome with steroid biosynthesis inhibitors. J Steroid Biochem Mol Biol 49:261-267

79. Moseley R (2007) Antibacterial and antifungal agents. In: Kaplowitz N, DeLeve L (eds) Drug-induced liver disease, 2nd edn. Informa Healthcare USA, New York, pp 527-546

80. Biller BM, Colao A, Petersenn S, Bonert VS, Boscaro M (2010) Prolactinomas, Cushing's disease and acromegaly: debating the role of medical therapy for secretory pituitary adenomas. BMC Endocr Disord 10:10. doi:10.1186/1472-6823-10-10

81. Castinetti F, Morange I, Jaquet P, Conte-Devolx B, Brue T (2008) Ketoconazole revisited: a preoperative or postoperative treatment in Cushing's disease. Eur J Endocrinol 158:91-99. doi:10.1530/ EJE-07-0514

82. Baudry C, Coste J, Bou Khalil R, Silvera S, Guignat L, Guibourdenche J, Abbas H, Legmann P, Bertagna X, Bertherat J (2012) Efficiency and tolerance of mitotane in Cushing's disease in 76 patients from a single center. Eur J Endocrinol 167:473-481. doi:10.1530/EJE-12-0358

83. Pivonello R, Fleseriu M, Guignat L, Zhang Y, Robinson P, Taylor A, Watson C, Maldonado M, Hamrahian AH, Boscaro M, Biller BM (2012) Patients with Cushing disease achieve normal urinary cortisol with LCI699, a potent $11 \beta$-hydroxylase inhibitor: preliminary results from a multicenter, proof-of-concept study. Endocr Rev 33:OR49-41

84. ClinicalTrials.gov (2012) NCT NCT01331239. http://clinicaltrials. gov/ct2/show/NCT01331239. Accessed $21 \mathrm{Feb} 2013$

85. Fleseriu M (2012) Medical management of persistent and recurrent Cushing disease. Neurosurg Clin N Am 23:653-668. doi:10.1016/j.nec.2012.06.012

86. Fleseriu M, Petersenn S (2012) Medical management of Cushing's disease: what is the future? Pituitary 15:330-341. doi: $10.1007 / \mathrm{s} 11102-012-0397-5$

87. Petersenn S (2011) Medical management of Cushing's disease. In: Swearingen B, Biller B (eds) Endocrine updates: Cushing's disease, vol 31. Springer, New York, pp 167-182 